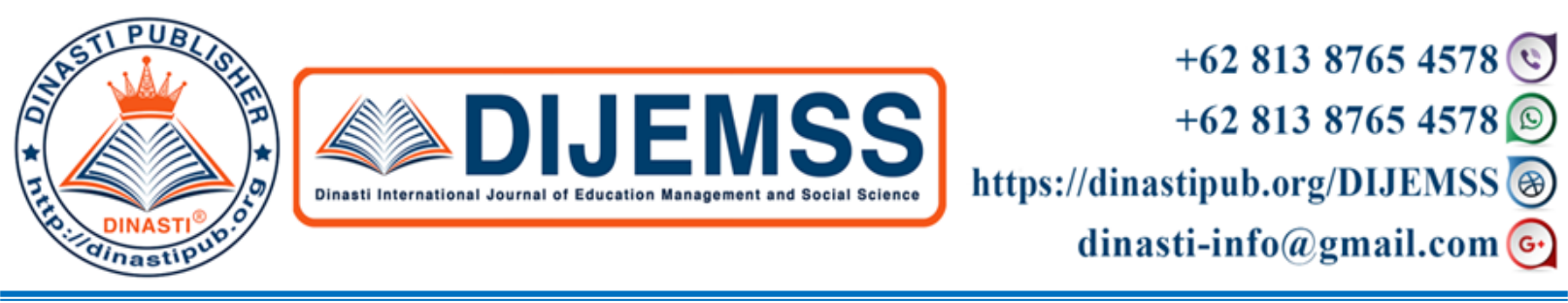

\title{
THE EFFECT OF CHARACTERISTICS AND ENTREPRENEURSHIP OF THE STUDENTS 'INTEREST IN VOCATIONAL SCHOOL WITH MOTIVATION AS A VARIABLE OF MEDIATION
}

\section{Imam Faisal}

Mercu Buana University, Jakarta, Indonesia

ARTICLE INFORMATION

Received: $16^{\text {th }}$ June 2020

Revised: $25^{\text {th }}$ July 2020

Issued: $22^{\text {th }}$ August 2020

Corresponding author:

First Author

E-mail:

immfisl@gmail.com

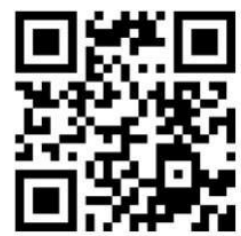

DOI:10.31933/DIJEMSS
Abstract: The background of this study is the high unemployment rate in Indonesia and the biggest contributor to unemployment in Indonesia is vocational graduates, this study aims to determine the effect of entrepreneurial characteristics, knowledge and motivation on entrepreneurial interest both simultaneously and partially, with entrepreneurship motivation as a mediating variable. This type of research is causality by clicking $g$ unakan approach is quantitative. The study population was students of SMK Global Informatika. The sampling technique uses probability sampling method. The number of samples determined was 95 respondents. Methods of data analysis using structural equation model with descriptive statistical tests, the validity and reliability of data and hypothesis testing using SmartPLS program Version 3. 0 for Windows. B erdasarkan test results determination coefficient result in the value of $\mathrm{R}-\mathrm{S}$ quare respectively at 0,489 to 0,646 for the motivation and interest in entrepreneurship, it refers $\mathrm{k}$ an effect of variable characteristics and entrepreneurial knowledge on the motivation of entrepreneurship of 48.9 per cent, then the influence of the characteristics, entrepreneurial knowledge and motivation was 64.6 percent, while the remaining 51.1 percent and 35.4 percent were influenced by other factors not examined. The results of this study indicate that : (1) entrepreneurial characteristics and knowledge have a significant positive effect on entrepreneurial motivation ; (2) the characteristics, knowledge and motivation of entrepreneurship have a significant positive effect directly on entrepreneurial interest ; (3) When the characteristics and entrepreneurial knowledge mediated by variab el entrepreneurship motivation, both variables have the effect of partial mediation interest in entrepreneurship.

Keywords: Characteristics, knowledge, motivation, interest entrepreneurship. 


\section{INTRODUCTION}

The unemployment rate in Indonesia has decreased in the last 2 years, but it is still not enough considering the number of unemployed people in Indonesia is very much, to overcome the high unemployment rate in Indonesia, the most appropriate way is by entrepreneurship. The low number of entrepreneurs in Indonesia is still relatively small, namely $5 \%$ of the total population of Indonesia.

The highest unemployment rate in Indonesia is generated by SMK graduates, where those who should have graduated from SMK directly have jobs after graduating school education, but in BPS data states SMK graduates are the largest contributing graduates in unemployment in Indonesia.

Based on unemployment data that has been obtained in Banten province, Serang Regency has the largest unemployment percentage of $10.65 \%$ and the lowest unemployment percentage is South Tangerang at $4.79 \%$ while Tangerang City itself has an unemployment rate of $7.13 \%$ unemployment Tangerang City exceeded the national figure of $6.2 \%$ and from this data the highest contributor to unemployment was SMK graduates.

The total unemployment rate of Tangerang City based on graduates is as follows: $0 \%$ elementary school graduates followed by $1 \%$ Diploma graduates then $4 \%$ Junior and University graduates and 24\% High School graduates and the highest is 67\% SMK graduates, this figure is astounding more than $60 \%$ of the unemployment contributors are vocational graduates.

Students' insights and abilities acquired in Vocational High Schools (SMK) are needed not only as a basic asset for students to prepare themselves in the workforce but also used to prepare students to become entrepreneurs. Global Informatics Vocational School is one of the vocational schools in Tangerang City, the absence of entrepreneurial learning at this school makes students' interest in entrepreneurship diminish. Entrepreneurship education is needed for Tangerang City Vocational School graduates in order to create entrepreneurial character and increase the motivation of vocational school graduates not only to focus on looking for work but to create jobs (Tangerang City Mayor, Arief R Wismansyah, 2019)

Based on the above phenomenon, the researcher wants to conduct research on the Effect of Entrepreneurial Characteristics and Knowledge on Entrepreneurial Interest Mediated by Entrepreneurial Motivation on Vocational Students in Global Informatics Tangerang City in Academic Year 2019/2020. The researcher has conducted a pre-survey beforehand on the students of the Global Vocational School of Informatics Tangerang City with the following results :

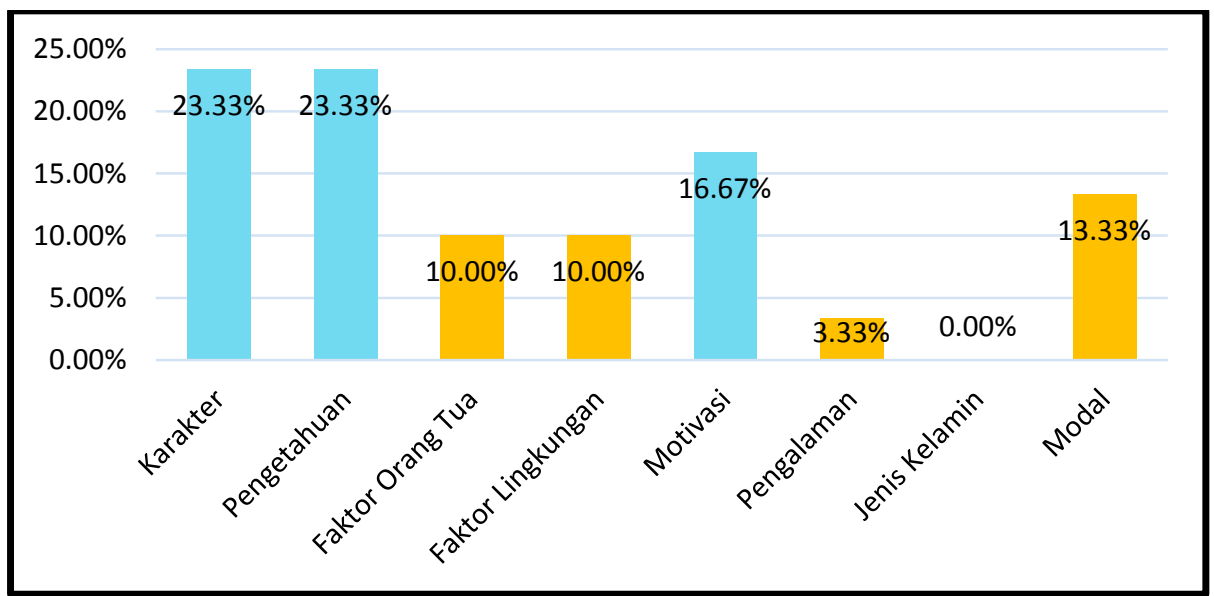

Figure 1. Pre-Survey Results that Affect Entrepreneurial Interest 
Table 1. Characteristics of Entrepreneurship

\begin{tabular}{|c|c|c|c|c|}
\hline No & Question & Yes & Not & Total \\
\hline 1 & I like to look for new challenges with entrepreneurship & $\begin{array}{c}8 \\
26.67 \%\end{array}$ & $\begin{array}{c}22 \\
73.33 \%\end{array}$ & $\begin{array}{c}30 \\
100 \%\end{array}$ \\
\hline 2 & I often look for new ways in various ways & $\begin{array}{c}9 \\
30 \%\end{array}$ & $\begin{array}{c}21 \\
70 \%\end{array}$ & $\begin{array}{c}30 \\
100 \%\end{array}$ \\
\hline 3 & I used to think of risks before acting & $\begin{array}{c}5 \\
16.67 \%\end{array}$ & $\begin{array}{c}25 \\
83.33 \%\end{array}$ & $\begin{array}{c}30 \\
100 \%\end{array}$ \\
\hline 4 & I work on what other people have needed & $\begin{array}{c}19 \\
63.33 \%\end{array}$ & $\begin{array}{c}11 \\
36.67 \%\end{array}$ & $\begin{array}{c}30 \\
100 \%\end{array}$ \\
\hline
\end{tabular}

Table 2. Entrepreneurial Knowledge

\begin{tabular}{clccc}
\hline No & \multicolumn{1}{c}{ Question } & Yes & Not & Total \\
\hline \multirow{2}{*}{1} & I know how to implement prestative work behavior as an entrepreneur & 6 & 24 & 30 \\
& & $20 \%$ & $80 \%$ & $100 \%$ \\
2 & I know how to manage entrepreneurial conflicts & 4 & 26 & 30 \\
& & $13.33 \%$ & $86.67 \%$ & $100 \%$ \\
\multirow{2}{*}{3} & I know how to analyze business opportunities based on the type of business I & 9 & 21 & 30 \\
& am interested in (services, trade and industry) & $30 \%$ & $70 \%$ & $100 \%$ \\
\hline
\end{tabular}

Table 3. Entrepreneur Motivation

\begin{tabular}{clccc}
\hline No & \multicolumn{1}{c}{ Question } & Yes & Not & Total \\
\hline \multirow{2}{*}{1} & I have a high personal responsibility to be an entrepreneur & 11 & 19 & 30 \\
& & $36.67 \%$ & $63.33 \%$ & $100 \%$ \\
2 & I dare to face all risks with full calculation in entrepreneurship & 9 & 21 & 30 \\
& & $30 \%$ & $70 \%$ & $100 \%$ \\
\multirow{2}{*}{3} & I need feedback to see the success or failure of what I do & 15 & 15 & 30 \\
& & $50 \%$ & $50 \%$ & $100 \%$ \\
\hline
\end{tabular}

\section{LITERATURE REVIEW}

\section{Entrepreneurship}

Entrepreneurship is an innovative and creative ability that is used as a starting point, strategy, and resources to find opportunities to succeed. The subject of entrepreneurship is the ability to create something new and diverse with creative ideas and innovations to realize opportunities. Many entrepreneurs and non-entrepreneurs achieve success because they have creative and innovative abilities (Suryana, 2010 in Ine Ruswati, 2018). (Havidz Aima, 2015 in Zaenal Afandi, 2019) Entrepreneurship is a creative and innovative ability that is the basis for it, tips and resources for finding opportunities for success. The point is the ability to create something new and different through creative thinking and innovative acting to look for opportunities in facing life's challenges.

\section{Characteristics of Entrepreneurship}

According to Peter F. Drucker in Rintan Sargih $(2017,2)$ explains that entrepreneurship is the nature, character, and characteristics inherent in someone who has a strong will to realize innovative ideas into the real business world and can develop them. Entrepreneur is someone who is free and has the ability to live independently in carrying out their business activities or business or life. Free to design, determine, manage, control all businesses. Entrepreneurship is a mental attitude and spirit that is always active or creative in trying to increase business income. The conclusion of entrepreneurship is the process of creating something of different 
value by using the effort and time required, taking the risks, psychological and social issues that accompany it, and accepting monetary rewards and personal satisfaction.

\section{Entrepreneurship Knowledge}

Entrepreneurial knowledge is the whole of what is known about all forms of information that are processed and processed in the context of a cognitive form of memory and understanding of ways of trying to cause courage to take risks rationally and logically in handling a business. Entrepreneurial knowledge can be obtained through entrepreneurship subjects. Entrepreneurship subjects are theoretical to increase entrepreneurial knowledge, while entrepreneurship subjects in the form of direct practice to enter the business field can generate creativity and innovation that can create new ideas or opportunities that can be exploited.

\section{Entrepreneurial Motivation}

Every person in taking action can not be separated from the existence of motivation. Motivation is closely related to the desire to achieve something better. Motivation is one of the things that motivates someone to do something to achieve a certain goal. This is consistent with the opinion of Sardiman (2012: 73) that motivation comes from the word motive which can be interpreted as a driving force from within and within the subject to carry out certain activities in order to achieve a goal.

According to Stephen P. Robbins and Timothy A. Judge (2015: 127) states motivation as a process that explains the strength, direction and perseverance of a person in an effort to achieve goals.

In Lia Lusiana Ritonga and Juanda Sianipar (2016: 73) entrepreneurial knowledge is all information or various symptoms encountered and known by humans through the five senses and their reasoning about an effort to build a value with ability, courage, determination and courage and take courage risk in the opportunity to succeed to open a business in various opportunities by knowing what are the factors that become the base of success towards success.

\section{Entrepreneurial Interest}

Entrepreneurial interest is the availability to work hard and diligently to achieve business goals. Availability to bear various risks related to entrepreneurial actions taken and a strong will to be independent or try to meet their own needs without feeling afraid of the risks that will occur and learn from failure.

According to Subandono (in Afif Nur Rahmadi and Heryanto 2016: 156) entrepreneurial interest is the tendency of the heart within the subject to be interested in creating a business that then organizes, organizes, bears the risk and develops the business that it creates.

\section{Framework}

Interest is a concentration of one's attention on a matter because it is pleasing to him, followed by a desire to learn and approach it further. Entrepreneurial interest will not just appear, many factors affect someone's interest in entrepreneurship, both in internal and external factors.

Thus if someone has the characteristics and knowledge of entrepreneurship plus motivation, it will have an influence on the interest in entrepreneurship. The three components are mutually supportive and interrelated to foster student interest in entrepreneurship.

Based on the description above, researchers determined a number of variables examined later, consisting of the independent variable (X), namely Characteristics (X1) and 
Entrepreneurship Knowledge (X2). While the dependent variable (Y) is Entrepreneurial Motivation (Y1), and Entrepreneurial Interest (Y2). So, the mindset in this study is as follows:

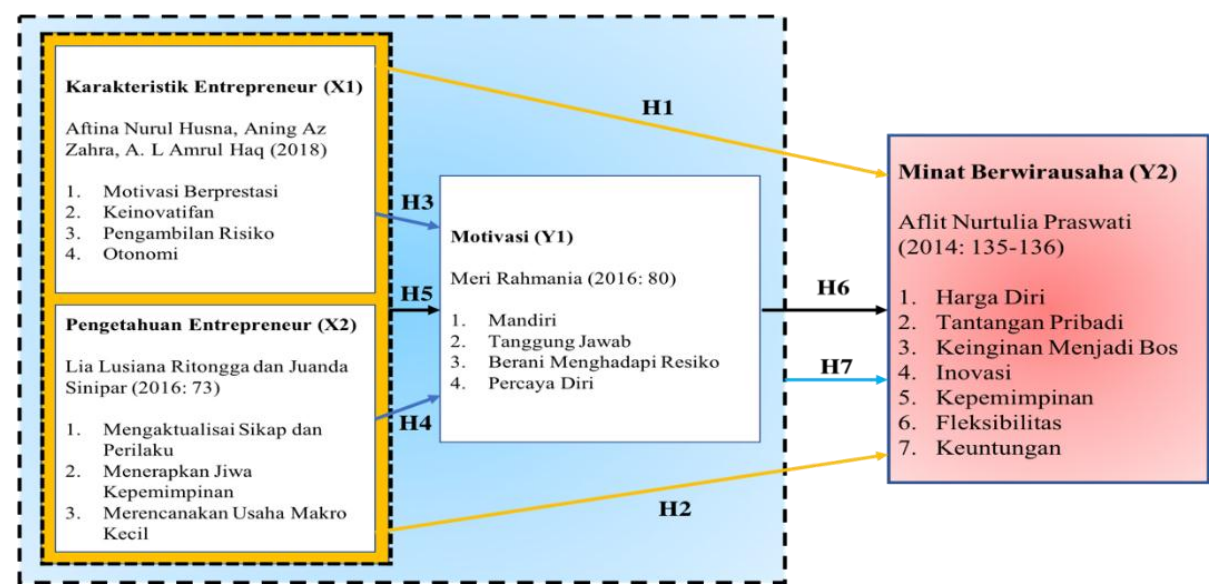

Figure 2. Framework

Hypothesis

Hypothesis 1 : Entrepreneurial characteristics significantly influence the interests of entrepreneurship.

Hypothesis 2 : Entrepreneurial knowledge significantly influences entrepreneurial interest.

Hypothesis 3 : Entrepreneurial characteristics significantly influence motivation.

$\mathrm{H}$ ipotesis 4 : Knowledge entrepreneurial significant effect on motivation.

$\mathrm{H}$ ipotesis 5 : The characteristics and knowledge of entrepreneurship together have a significant effect on motivation.

Hypothesis 6 : Motivation has a significant effect on interest in entrepreneurship.

Hypothesis 7 : The characteristics, knowledge and motivation of entrepreneurship together have a significant effect on entrepreneurial interest.

Hypothesis 8 : Significant motivation mediates the characteristics and knowledge of entrepreneurship towards entrepreneurial interest.

\section{RESEARCH METHOD}

This type of research used in this research is quantitative research. The data used in this study are primary data in the form of survey results. To collect complete, significant, and complementary data, besides primary data, the authors also use secondary data. This research was conducted to understand, describe, and analyze the relationship between the independent variable and the dependent variable. The analysis used in this study is the relevant statistical data to test hypotheses. Therefore, the data obtained in this study can later provide a clear picture of the object under study, and then, conclusions can be made. The research variables explained in the dimensions, indicators, and question items as data collection instruments can be seen in Table 4 .

Table 4 . Variables, dimensions, indicators, and items number of research

\begin{tabular}{llll}
\hline \multicolumn{1}{c}{ Variable } & \multicolumn{1}{c}{ Dimension } & \multicolumn{1}{c}{ Indicator } & No. Item \\
\hline $\begin{array}{l}\text { Entrepreneurship } \\
\text { Knowledge }\end{array}$ & $\begin{array}{l}\text { Actualizing attitudes and } \\
\text { behaviors }\end{array}$ & $\begin{array}{l}\text { Identification of entrepreneurial attitudes and } \\
\text { behavior }\end{array}$ & 11 \\
\cline { 2 - 3 } & & Implementing prestigious work behavior & 12
\end{tabular}


Decision making process $\quad 13$

Developing enthusiasm 14

Develop self commitment 15

Take a risk 16

Formulate solutions to problems $\quad 17$

Unyielding attitude 18

Implement the Soul of Leadership

Analyzing aspects of business management 19

Building a vision and mission 20

Analyzing business opportunities $\quad 21$

Plan small macro businesses

Analyzing aspects of business management 22

Reducing dependency 23

$\begin{array}{llll}\text { Motivation } & \text { Mandiri decisions with confidence } & 24\end{array}$

Trying to take the initiative in everything 25

\begin{tabular}{lll}
\hline & High personal responsibility & 26 \\
Responsible & Perform the task thoroughly & 27 \\
& Carry out the tasks well & 28 \\
\hline
\end{tabular}

Dare to face risk

Deal with risks with calculations 29

\begin{tabular}{ll} 
Love a challenge & 30 \\
\hline Waiting for success & 31
\end{tabular}

Confidence

Optimistic 32

Take action without hesitation

\begin{tabular}{lllr} 
Variable & Dimension & Indicator & No. Item \\
\hline & & More appreciated & 34 \\
Entrepreneurial & Pride & More confident & 35 \\
& & Comfortable talking with others & 36 \\
\cline { 2 - 3 } & Personal Challenge & Want to try new things & 37 \\
& Liked things to get ahead & 38 \\
\cline { 2 - 3 } & Do what other people do & 39 \\
\hline & The desire to be a boss & The desire to freely manage their own business & 40 \\
& & 41 \\
& & Want to be able to develop your own business & 42 \\
\hline
\end{tabular}




\begin{tabular}{lll}
\hline \multirow{2}{*}{ Innovation } & Happy creative thing & 43 \\
& Want to make things different & 44 \\
& Glad to do the experiment & 45 \\
\hline & Nice to talk with the crowd & 46 \\
Leadership & Want to be the captain of the team & 47 \\
& Want to stand out more & 48 \\
\hline Flexibility & Doesn't like to be attached & 49 \\
& Irregular & 50 \\
& Happy with non-binding work & 51 \\
\hline & Want to be free to run your own finances & 52 \\
& Want to feel your own wealth & 53 \\
& Want to develop your own business & 54
\end{tabular}

\section{Population and Sample}

Population is a group of people, events, or interesting things where researchers want to make an opinion (based on sample statistics) (John Wiley \& Sons, 2013: 53). The population can be subjects or research objects. The population of this research is Vocational School Students in Tangerang City, Banten, who are still active in learning activities in Schools.

The sample is a portion of the population. The sample consists of a number of members selected from the population. In other words, some but not all, population elements are in the form of samples. (John Wiley \& Sons, 2013: 54). The sample taken is using the census method in which the entire population is sampled (probability saturation sampling), so to measure the sample of vocational students the Slovin formula is used with a leeway of 5\% (Prasetyo, 2006) as follows:

$$
\begin{aligned}
& \mathrm{n}=\frac{N}{1+N(e)^{2}} \\
& \mathrm{n}=\frac{123}{1+123(0.05)^{2}}=94,072
\end{aligned}
$$

Based on the formula above, the minimum number of samples taken is a number of 94,072, and will be rounded up to 95 samples. For the sampling technique to be used is Probability Sampling, the probability sampling design is used when the level of representation of the sample is important in broader generalizations. (John Wiley and Sons, 2013)

\section{Method of Analysis}

This study uses data analysis techniques using SmartPLS version 3.2.8 software that is run on computer media. PLS (Partial Least Square) is a structural equation analysis (Structural Equation Modeling) or abbreviated as SEM based on variants which can simultaneously test measurement models while testing structural models. 


\section{RESULTS AND DISCUSSION}

The tests used in this study are the measurement model / outer model and the structural / inner model test.

\section{Evaluation of the Reflective Measurement Model (Outer Model) or Test Indicator}

Below is a picture of the results of the calculation of the measurement model with SEM PLS version 3.2.8 which is then seen by the loading value factor on the indicator in each research variable. The loading factor value used in this study is $>0.6$. Therefore, if the value of the loading factor is $<0.6$, the results per count of the measurement model (outer model) will be removed from the model.

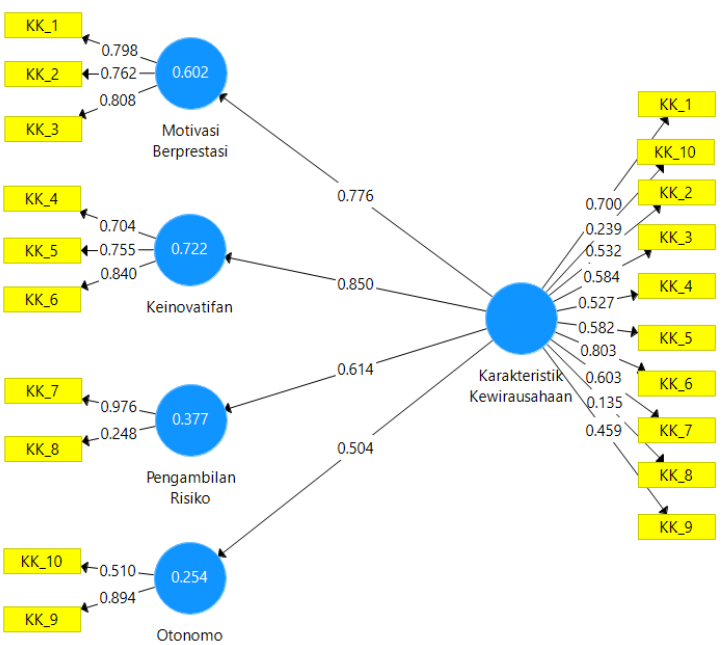

Figure 3. Calculation Result of Measurement Model (Outer Model) of Characteristic Variables

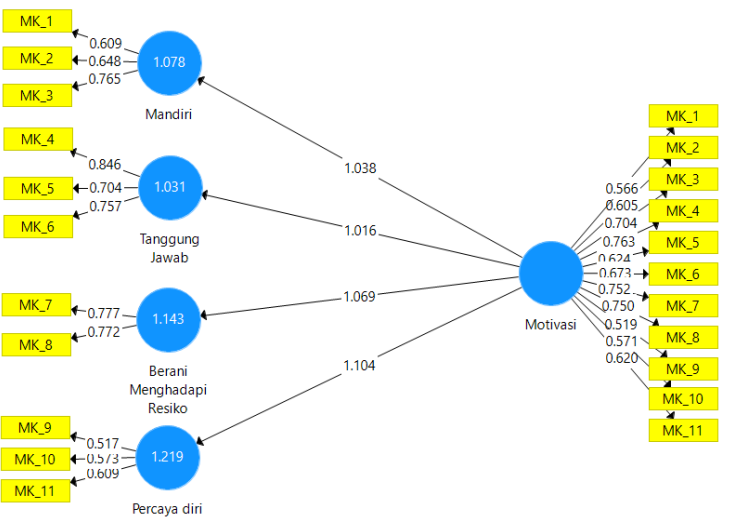

Figure 5. Calculation Result of Measurement Model (Outer Model) of Motivational Variables

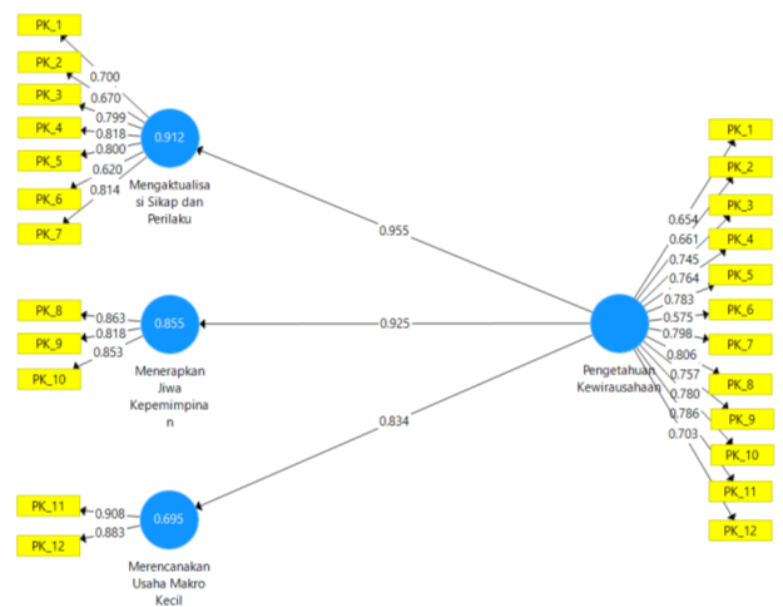

Figure 4. Calculation Result of Measurement Model (Outer Model) of Knowledge Variables

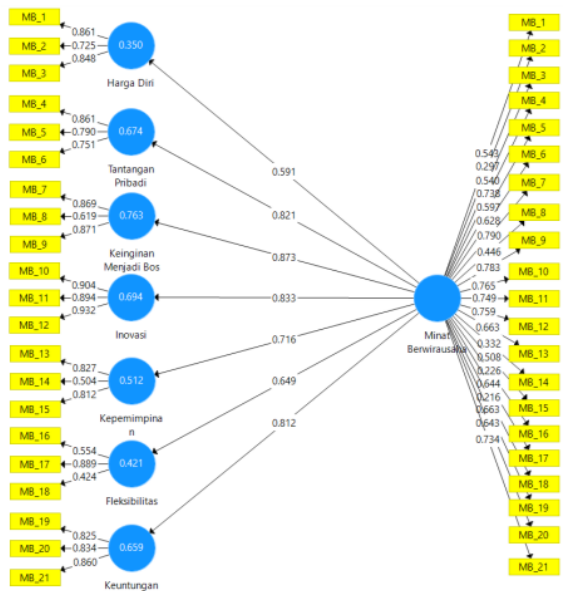

Figure 6 . Measurement Model Calculation Results (Outer Model) of Knowledge Variables

Evaluation of convergent validity from the examination of Average variance extracted (AVE) illustrates the magnitude of the variance or diversity of manifest variables that can be possessed by latent constructs. The greater the variance or diversity of manifest variables that 
can be contained by latent constructs, the greater the representation of manifest variables to their latent constructs. Evaluation of convergent validity from the examination of Average Variance Extracted (AVE) can be seen from the value of AVE based on the results of data processing with SmartPLS version i 3.2.8 in Table 5 .

Table 5. Average Variance Extracted (AVE) Value for Each Variable

\begin{tabular}{lc}
\hline \multicolumn{1}{c}{ Variable } & Average Variance Extracted (AVE) \\
\hline Entrepreneurship Characteristics & 0.595 \\
Entrepreneurship Knowledge & 0.566 \\
Motivation & 0.549 \\
Entrepreneurial Interest & 0.534 \\
\hline
\end{tabular}

The results of the above calculations are known that the value of AVE for all variables has a value of AVE> 0,5 , each of 0.595 for entrepreneurial characteristics, 0.566 for entrepreneurial knowledge, 0.549 for motivation, and 0.534 for entrepreneurial interest.

Evaluation of convergent validity from internal consistency reliability checks can be seen from the value of Cronbach 's Coefficient Alpha and Composite Reliability (CR) shown in Table 5. The table presented is the result of SmartPLS calculation version 3.2.8.

Table 6. Values of Cronbach's Coefficient Alpha and Composite Reliability (CR)

\begin{tabular}{lcc}
\hline \multicolumn{1}{c}{ Variable } & Cronbach's Coefficient Alpha & Composite Reability (CR) \\
\hline Characteristics & 0.654 & 0.814 \\
Knowledge & 0.923 & 0.935 \\
Motivation & 0.880 & .906 \\
Entrepreneurial Interest & 0.920 & 0.931 \\
\hline
\end{tabular}

As shown in table 6, it is known that the Cronbach's Coefficient Alpha value and composite reliability for the studied variables are entrepreneurial character, entrepreneurial knowledge, motivation and entrepreneurial interest more than 0.6 or even close to 1 and the Composite reliability (CR) value is more than 0, 80 This value has exceeded the standard, respectively $>0.6$ and $>0.7$, so that all variables in the study are declared reliable.

While the Composite Reliability (CR) value for the compensation variable is 0979 , $\mathrm{j}$ ob s atisfaction is 0.966 , m otivation is 0.980 , and p roductivity is 0.975 . Thus, it can be seen that the Composite Reliability (CR) value for all variables is $>0.8$. Based on this, it can be concluded that all variables used in the study are very reliable.

\section{Discriminant Validity Test}

The validity of the indicators on each of the research variables can also be done by testing the discriminant validity by checking the cross-loading value, which is the indicator correlation coefficient on its construct compared to the correlation coefficient with other constructs. The value of the indicator correlation coefficient must be greater in constructs than for other constructs. 
Table 7. Testing Descriminant Validity Se has Modifications

\begin{tabular}{|c|c|c|c|c|c|}
\hline Indicator & Characteristics & Knowledge & Motivation & Entrepreneurial Interest & Information \\
\hline KK_1 & .709 & .497 & .457 & 0.529 & Valid \\
\hline KK_2 & 0.575 & .338 & .344 & .478 & Valid \\
\hline KK_3 & 0.637 & .441 & 0.335 & .482 & Valid \\
\hline KK_4 & 0.550 & .324 & .406 & .456 & Valid \\
\hline KK_5 & 0.565 & .271 & .363 & 0.285 & Valid \\
\hline KK_6 & 0.805 & .396 & .458 & 0.502 & Valid \\
\hline KK_7 & 0.563 & .406 & .396 & .406 & Valid \\
\hline KK_9 & .403 & 0.299 & .401 & 0.160 & Valid \\
\hline PK_1 & .400 & 0.664 & 0.480 & .452 & Valid \\
\hline PK_2 & 0.559 & .677 & 0.525 & 0.551 & Valid \\
\hline PK_3 & 0.419 & 0.744 & 0.460 & 0.421 & Valid \\
\hline PK_4 & 0.466 & 0.761 & 0.503 & 0.512 & Valid \\
\hline PK_5 & 0.439 & .777 & .483 & .443 & Valid \\
\hline PK_6 & 0.462 & $\mathbf{0 . 5 8 7}$ & 0.548 & .323 & Valid \\
\hline PK_7 & 0.431 & .806 & 0.555 & 0.492 & Valid \\
\hline PK_8 & .448 & 0.805 & 0.612 & 0.575 & Valid \\
\hline PK_9 & 0.467 & .758 & .486 & 0.436 & Valid \\
\hline PK_10 & 0.512 & .771 & 0.510 & 0.496 & Valid \\
\hline PK_11 & .368 & 0.768 & .400 & .456 & Valid \\
\hline PK_12 & 0.462 & .696 & .398 & 0.503 & Valid \\
\hline MK_1 & .403 & 0.389 & 0.593 & 0.425 & Valid \\
\hline MK_2 & .372 & 0.411 & .626 & 0.424 & Valid \\
\hline MK_3 & 0.517 & .498 & .757 & 0.599 & Valid \\
\hline MK_4 & 0.584 & .661 & 0.826 & .686 & Valid \\
\hline Indicator & Characteristics & Knowledge & Motivation & Entrepreneurial Interest & Information \\
\hline MK_5 & 0.319 & 0.218 & 0.660 & .477 & Valid \\
\hline MK_6 & 0.412 & 0.412 & 0.717 & 0.535 & Valid \\
\hline MK_7 & 0.545 & 0.606 & 0.799 & .647 & Valid \\
\hline MK_8 & 0.558 & 0.636 & $\mathbf{0 . 7 8 7}$ & 0.622 & Valid \\
\hline MK_9 & .323 & 0.313 & 0.540 & .479 & Valid \\
\hline MK_10 & .368 & .385 & 0.594 & 0.485 & Valid \\
\hline MK_11 & 0.390 & .447 & $\mathbf{0 . 6 3 7}$ & .487 & Valid \\
\hline MB_1 & 0.430 & 0.212 & .284 & 0.510 & Valid \\
\hline MB_3 & 0.416 & .394 & 0.432 & 0.523 & Valid \\
\hline MB_4 & 0,600 & .459 & 0.644 & 0.760 & Valid \\
\hline MB_5 & 0.435 & .346 & 0.514 & 0.597 & Valid \\
\hline MB_6 & .408 & 0.411 & 0.642 & 0.644 & Valid \\
\hline MB_7 & 0.599 & 0.588 & .684 & 0.790 & Valid \\
\hline
\end{tabular}




\begin{tabular}{cccccc}
\hline MB_8 & 0.225 & .229 & .243 & $\mathbf{0 . 4 1 6}$ & Valid \\
\hline MB_9 & 0.510 & 0.503 & 0.615 & $\mathbf{0 . 7 9 8}$ & Valid \\
\hline MB_10 & 0.556 & 0.566 & 0.607 & $\mathbf{. 7 7 9}$ & Valid \\
\hline MB_11 & 0.510 & 0.508 & 0.583 & $\mathbf{0 . 7 8 3}$ & Valid \\
\hline MB_12 & 0.604 & .653 & .661 & $\mathbf{0 . 7 8 9}$ & Valid \\
\hline MB_13 & .458 & .486 & 0.579 & $\mathbf{. 6 8 1}$ & Valid \\
\hline MB_14 & 0.254 & .298 & .291 & $\mathbf{0 . 3 0 4}$ & Valid \\
\hline MB_16 & -0.02, & 0.078 & $-0,016$. & $\mathbf{0 . 1 7 0}$ & Valid \\
\hline MB_17 & .368 & .328 & 0.425 & $\mathbf{. 6 2 7}$ & Valid \\
\hline MB_18 & .138 & 0.064 & 0.055 & $\mathbf{. 1 7 3}$ & Valid \\
\hline MB_19 & 0.450 & .387 & 0.433 & $\mathbf{0 . 6 4 4}$ & Valid \\
\hline MB_20 & .396 & 0.255 & 0.370 & $\mathbf{0 . 6 3 2}$ & Valid \\
\hline MB_21 & 0.413 & 0.325 & 0.434 & $\mathbf{0 . 7 1 6}$ & Valid \\
\hline
\end{tabular}

Based on the results of discriminatory validity testing after the modification model as shown in table 7 above, shows that the indicator has a cross loading value to the construct is greater than the value of the cross loading to the construct so it is valid. It can be denied that the constructs, knowledge, motivation, and interests of entrepreneurship have good discriminatory validity.

\section{Evaluation of the Structural Model (Inner Model) or Hypothesis Test \\ 1. Evaluate the Path Coefficient Value}

In evaluating the path coefficient, based on the results of calculations using SmartPLS version 3.2.8 bootstrap, the path coefficient results obtained illustrate the strength of the relationship between constructs / variables such as i shown in Figure 7 as follows:

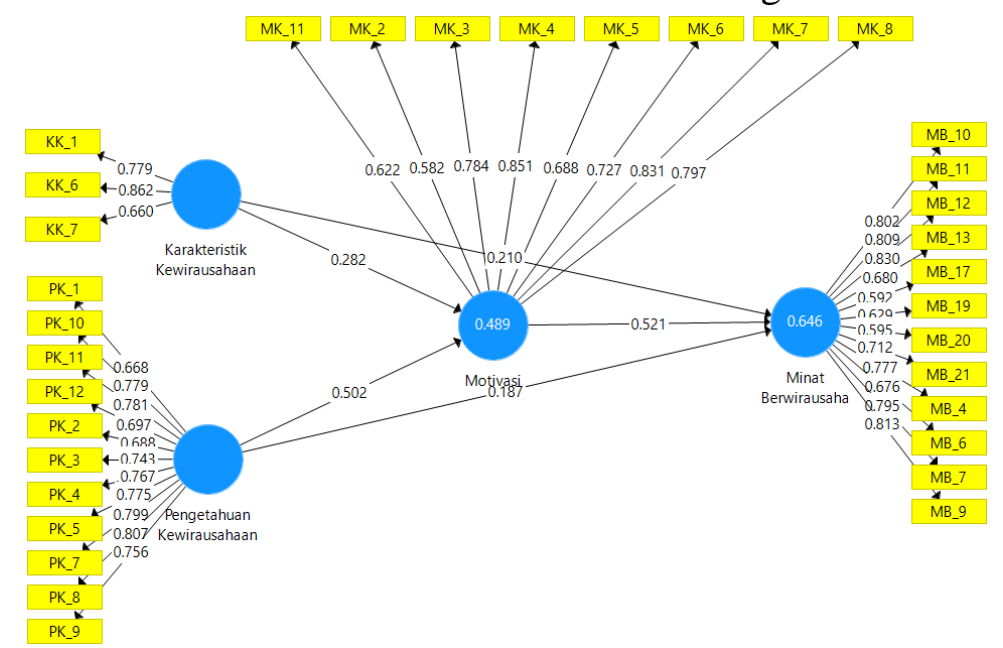

Figure 7 Results of Bootstrapping Measurement Model Calculations

The results in Figure 7 structural equation from this study are formulated as follows:

T table value ( df2 $=95-4)$ alpha $0.05=1.98$

Motivation $(\mathrm{Y} 1)=0.282(\mathrm{X} 1)+0.502(\mathrm{X} 2)$

Entrepreneurial Interest $(\mathrm{Y} 2)=0.210(\mathrm{X} 1)+0.187(\mathrm{X} 2)+0.521(\mathrm{Y} 1)$ 


\section{Evaluating the $\mathbf{R}^{2}$ Value}

To determine the value of $\mathrm{R}^{2}$ based on calculations using the calculate SmartPLS 3.0 showed the value of $\mathrm{R}^{2}$ is 0.489 and 0.646 for motivation variable to variable interest in entrepreneurship. The value of $\mathrm{R}^{2}$ indicates that the level of determination of exogenous variables (characteristics and entrepreneurial knowledge) against endogennya (motivation and interest in entrepreneurship is quite high. The effect of simultaneous variable characteristics and knowledge of the motivation (Y1) can be done by calculating the arithmetic f / f statistic as follows.

a. $\mathrm{R}^{2}=0,489(\mathrm{Y} 1)$

$$
\begin{aligned}
& \mathrm{F} \text { count }=\frac{\frac{R^{2}}{(k-1)}}{1-R^{2} /(n-k)} \\
& \mathrm{F} \text { count }=\frac{\frac{0.489}{(4-1)}}{1-0,489 /(95-4)} \\
& \mathrm{F} \text { count }=\frac{0,16}{0,0056} \\
& \mathrm{~F} \text { count }=29.03
\end{aligned}
$$

The simultaneous effect of characteristic variables, entrepreneurial knowledge and motivation on Entrepreneurial Interest (Y2) can be done by calculating f arithmetic / f statistics using the following formula.

b. $\mathrm{R}^{2}=0,646(\mathrm{Y} 2)$

$$
\begin{aligned}
& \text { F hitung }=\frac{\frac{R^{2}}{(k-1)}}{1-R^{2} /(n-k)} \\
& \text { F hitung }=\frac{\frac{0.646}{(4-1)}}{1-0,646 /(95-4)} \\
& \text { F hitung }=\frac{0,22}{0,0039} \\
& \text { F hitung }=55.35
\end{aligned}
$$

Significant test results were simultaneously used to test hypotheses 5 and 7 in this study. F count in this study is 29.03 and $55,35 \mathrm{~F}$ table at $(\mathrm{DF} 1=4-1 \mathrm{DF} 2=95-4)$ alpha 0:05

\begin{tabular}{|c|c|c|c|c|}
\hline & Characteristics & Knowledge & Motivation & $\begin{array}{l}\text { Entrepreneurial } \\
\text { Interest }\end{array}$ \\
\hline Characteristics & & & .107 & 0.077 \\
\hline Knowledge & & & 0.340 & 0.051 \\
\hline Motivation & & & & .391 \\
\hline
\end{tabular}
namely 2,70 . This means that $\mathrm{f}$ count $>\mathrm{f}$ Table $(2,70)$, then $\mathrm{H} 5$ and $\mathrm{H} 7$ are accepted and Ho is rejected .

\section{Measuring Effect Size F $^{2}$}

Objective measurement of effect size $\mathrm{f}^{2}$ to see the size of the latent variable exogenous influence on endogenous latent variables or to see the goodness of the model. The results of calculating the effect size (f square) value with SmartPLS 3.0 are shown in Table 8

Table 8. F square values 


\section{Validating the Overall Structural Model with the Goodness of Fit Index (GoF)}

The purpose of testing the Goodness of Fit Index $(G o F)$ is to validate the combined performance of the measurement model (outer model) and structural model (inner model) obtained through calculations as follows:

$$
\begin{aligned}
& \text { Gof }=\sqrt{A V E \times R^{2}} \\
& \text { Gof }=\sqrt{0,561 \times 0,568} \\
& \text { Gof }=\sqrt{0,319} \\
& \text { Gof }=0,5643
\end{aligned}
$$

Keterangan:

$A V E \quad=(0,595+0,566+0,549+0,534) / 4=2,244 / 4=0,561$

$\mathrm{R}$ square $\quad=(0,489+0,646) / 2=1,135 / 2=0,568$

The calculation result of the Goodness of Fit Index (GoF) shows the value of 0,5643 . Based on these results it can be concluded that the combined performance of the measurement model (outer model) and the structural model (inner model) as a whole is good because the Goodness of Fit Index (GoF) value is more than 0, 25 (moderate scale)

\section{Predictive Relevance Testing $\left(\mathbf{Q}^{2}\right)$}

The purpose of testing the predictive relevance $\left(Q^{2}\right)$ is to validate the model. The results of the $\mathrm{Q}^{2}$ calculation are as follows

$$
\begin{aligned}
& \mathrm{Q}^{2}=1-\left(1-\mathrm{R} 1^{2}\right)\left(1-\mathrm{R} 2^{2}\right) \\
& \mathrm{Q}^{2}=1-(1-0,489)(1-0,646) \\
& \mathrm{Q}^{2}=1-(1-0,511)(1-0,354) \\
& \mathrm{Q}^{2}=1-0,180894 \\
& \mathrm{Q}^{2}=0,819106
\end{aligned}
$$

Based on the predictive relevance (Q2) calculation above, the value is 0.82 . In this research model, endogenous latent variables have predictive relevance $\left(Q^{2}\right)$ values greater than 0 (zero) so that exogenous latent variables are suitable as explanatory variables that are able to predict their endogenous variables namely employee performance or in other words prove that this model is considered to have good predictive relevance.

\section{Results of the Effect of Independent Variables on Dependent Variables}

Hypothesis testing about the influence of exogenous variables of entrepreneurial characteristics (X1), entrepreneurial knowledge (X2) on endogenous variables of motivation (Y1), either partially or simultaneously and also entrepreneurial characteristics (X1), entrepreneurial knowledge (X2) and motivation (Y1) on entrepreneurial interest (Y2) and also following related to the effect of the mediator or the effect of the mediator in this case motivation. The results of statistical calculations with the SmartPLS 3.0 program are presented in Table 9 and Table 10 as follows.

Table 9 . Partial Effect of Independent Variables on Dependent Variables

\begin{tabular}{lcccc}
\hline & $\begin{array}{c}\text { Original } \\
\text { Samples } \\
(\mathbf{O})\end{array}$ & $\begin{array}{c}\text { Sample Mean } \\
(\mathbf{M})\end{array}$ & $\begin{array}{c}\text { Standard } \\
\text { Deviation } \\
\text { (STDEV) }\end{array}$ & $\begin{array}{c}\text { T Statistics (O / } \\
\text { STDEV) }\end{array}$ \\
\hline $\begin{array}{l}\text { Character of Entrepreneurship -> } \\
\text { Entrepreneurial Interest }\end{array}$ & 0.210 & 0.216 & 0.096 & 2,176 \\
\hline $\begin{array}{l}\text { Entrepreneurship Knowledge -> } \\
\text { Entrepreneurial Interest }\end{array}$ & .187 & .188 & 0.077 & 2,418 \\
\hline
\end{tabular}




\begin{tabular}{lccccc}
\hline $\begin{array}{l}\text { Character of Entrepreneurship -> } \\
\text { Motivation }\end{array}$ & .282 & .279 & .105 & 2,692 & 0.007 \\
\hline Entrepreneurship Knowledge -> Motivation & 0.502 & 0.514 & 0.081 & 6,226 & 0,000 \\
\hline $\begin{array}{l}\text { Motivation -> } \\
\text { Entrepreneurial Interest }\end{array}$ & 0.521 & 0.518 & 0.098 & 5,293 & 0,000 \\
\hline
\end{tabular}

Table 10. Effect of Independent Variables Simultaneously Against Dependent Variables

\begin{tabular}{cccccc}
\hline & R Square & F Statistics & F Table & Alpha & Conclusion \\
\hline$(\mathrm{X} 1, \mathrm{X} 2)$-> Y1 & .489 & 29.03 & 2.7 & 0.05 & $\begin{array}{c}\text { Fcount }>\text { Ftable }(\mathrm{H} 5 \\
\text { received })\end{array}$ \\
$(\mathrm{X} 1, \mathrm{X} 2, \mathrm{Y} 1)$ - > Y2 & 0.646 & 55.35 & 2.7 & 0.05 & $\begin{array}{c}\text { Fount }>\text { Ftable }(\mathrm{H} 7 \\
\text { received })\end{array}$ \\
\hline
\end{tabular}

Based on the table above, it can be concluded that the character, knowledge and motivation of entrepreneurship partially and simultaneously significantly influence the interest in entrepreneurship at the Global Vocational School of Tangerang City. Entrepreneurship motivation significantly mediating factor characteristics and knowledge of entrepreneurship in the interest of air wirausahaan SMK Kota Tangerang Global Informatics .

\subsection{Correlation Analysis Between Dimensions}

Correlation analysis between dimensions aims to measure the level of relationship between dimensions in variable $\mathrm{X}$ with dimensions in variables $\mathrm{Y} 1$ and $\mathrm{Y} 2$ and dimensions in variable Y1 with dimensions in variable Y2. This time the entrepreneurial characteristic variable consists of 4 dimensions, entrepreneurship knowledge variable consists of 3 dimensions, motivation variable consists of 4 dimensions and entrepreneurial interest variable consists of 7 dimensions

Correlation matrix between dimensions is intended to determine the dimensions of the independent variable (character and entrepreneurial knowledge) which has the highest correlation value with the dependent variable dimensions Y1 (motivation) and the dependent variable dimensions Y2 (entrepreneurial interest) and also to determine the dimensions of the dependent variable Y1 (motivation) which has the highest correlation value with the dependent variable dimension Y2 (entrepreneurial interest). The explanation is as shown in Table 11 and Table 12 as follows.

Table 1 1. Correlation Matrix Results Between Dimensions of Characteristic Variables (X1) and Entrepreneurship Knowledge (X2) with Entrepreneurial Motivation (Y1)

\begin{tabular}{|c|c|c|c|c|c|}
\hline \multicolumn{2}{|c|}{ RELATIONSHIP } & \multicolumn{4}{|c|}{ MOTIVATION (Y1) } \\
\hline VARIABLES & DIMENSIONS & Mandiri & Responsible & Dare to take risks & Confidence \\
\hline CHARACTERISTICS & Achievement motivation & 0.269 & .407 & 0.496 & .368 \\
\hline \multirow[t]{3}{*}{ (X1) } & Innovative & 0.527 & .374 & .484 & .392 \\
\hline & Risk_upload & .487 & .473 & 0.501 & 0.468 \\
\hline & Autonomy & 0.428 & 0.350 & .343 & .229 \\
\hline KNOWLEDGE & $\begin{array}{c}\text { Actualize } \\
\text { Attitude }\end{array}$ & 0.551 & 0.505 & .698 & 0.499 \\
\hline \multirow[t]{2}{*}{ (X2) } & $\begin{array}{c}\text { Apply_Soul__ } \\
\text { Leadership }\end{array}$ & 0.464 & 0.500 & .663 & .458 \\
\hline & Plans_Usaha_Makro_Small & .372 & 0.264 & 0.466 & 0.414 \\
\hline
\end{tabular}


Table 1 2. Results of Correlation Matrix Between Dimensions of Variable Characteristics (X1) and Knowledge (X2) and Motivation (Y1) with Entrepreneurial Interest (Y2)

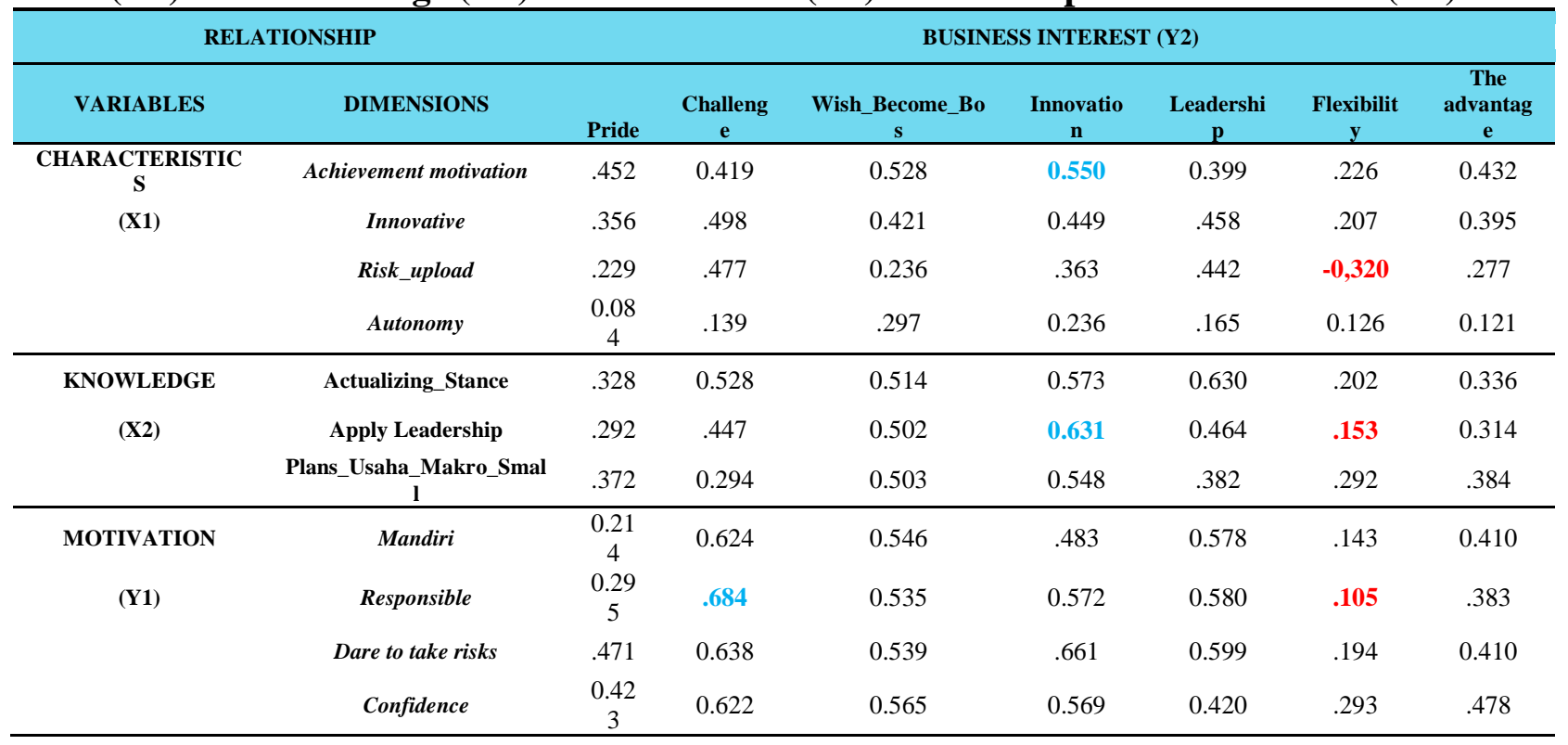

The results of testing Table 11 and Table 12 above can be concluded as follows.

1. In the variable characteristics of the variable motivation, correlation dimension of the most high is Keinovatifan the dimensions independently of 0.527 . While the lowest correlation dimension on this variable is the dimension of autonomy to the dimension of selfconfidence, which is equal to 0,229 .

2. On the variable knowledge of the variables of motivation, correlation dimension of the most high is actualizing the attitude and behavior towards risk-taking dimension of 0.698 . While the lowest correlation dimension on this variable is the dimension of planning a small macro business to the dimension of responsibility, which is equal to 0,264 .

3. In the variable characteristics of the variable interest in entrepreneurship, the correlation dimension of the most high is the dimension of the dimensions of achievement motivation on innovation amounted to 0,550 . While the lowest correlation dimension on this variable is the risk taking dimension to the flexibility dimension, which is - 0,320 .

4. On the variable knowledge to variable interest in entrepreneurship, the correlation dimension of the most high is the dimension of leadership apply to the leadership dimension of 0.631 . While the lowest correlation dimension on this variable is the dimension of applying leadership to the dimension of flexibility, which is equal to 0,153 .

5. At the motivation variable to variable interest in entrepreneurship , the correlation dimension of the most high is the dimension of responsibility to the dimensions of a personal challenge at 0.684 . While the lowest correlation dimension on this variable is the dimension of responsibility towards the flexibility dimension, which is equal to 0,105 .

\section{Discussion}

The effect of each research variable when linked to the theory and the results of previous studies can be explained in the discussion of research results in detail as follows: 
1. Hypothesis 1 - Effect of Entrepreneurial Characteristics GTerhadap Interests Entrepreneurship

The research findings show that the characteristics of entrepreneurship have a significant positive effect on entrepreneurial interest. That is, the better the characteristics possessed by students, the more influence they have on entrepreneurial interest. The results of this study are reinforced by the theory that states that entrepreneurial interest is driven by personal factors that concern a person, including the potential for entrepreneurial characteristics possessed by someone (Buchari Alma, 2013: 9).

This is in line with all research results that have been reviewed with results that prove the existence of a relationship or influence on the interests of entrepreneurship. Therefore, the higher the entrepreneurial characteristics possessed by students, it can directly increase the interest in entrepreneurship.

2. Hypothesis 2 - The Effect of Entrepreneurship Knowledge on Entrepreneurial Interest

Research findings show that entrepreneurial knowledge has a significant positive effect on entrepreneurial interest. That is, the better the knowledge possessed by students, the more influence the interest in entrepreneurship has. The results of this study are strengthened by the theory that entrepreneurship knowledge is all information or various symptoms encountered and known by humans through the five senses and their reasoning about an effort to build a value with ability, courage, determination and creativity and dare to take risks in the opportunity to succeed to open a business in various opportunities by knowing what are the factors that become success to success.

This is in line with the results of studies that have been reviewed such as the results of Vijeyan Samydevan's research, Shishi Kumum Piaralal, Abd Kadir Othman, Zahir Osman (2015), explained that entrepreneurial knowledge variables significantly influence entrepreneurial interest and the results of Erbu Dogan's research (2015) also explain that positive relationships which is significant between entrepreneurship education and entrepreneurial interest, and plays an important role in increasing entrepreneurial interest.

3. Hypothesis 3 - Effect of Entrepreneurship Characteristics on Entrepreneurial Motivation

The findings of this study indicate that entrepreneurial characteristics significantly influence motivation. That is, the higher the characteristics possessed by students, the higher the entrepreneurial motivation they have.

This is in line with the research that has been reviewed, the results of the study (Phutry Lellyzzia, 2018) explain that entrepreneurial characteristics have a positive and significant effect on entrepreneurial motivation, high characteristics of a person will provide motivation from within to entrepreneurship.

4. Hypothesis 4 - The Effect of Entrepreneurial Knowledge on Entrepreneurial Motivation

The findings of this study indicate that entrepreneurial knowledge has a significant effect on student entrepreneurship motivation. That is, the higher the knowledge possessed by students in entrepreneurship, the higher the motivation of entrepreneurship in their possession. Entrepreneurship is a knowledge that can be learned and taught, not just limited to scientific talent and experience, learning that has been held will increase a person to start entrepreneurship, and motivate someone to become an entrepreneur (Fa'izatul Masruroh, 2017). 
This is in line with the results of the research. The results of the study (Tri Cahyani Pangesti Leres, 2018) explain that entrepreneurial knowledge has a significant positive effect on entrepreneurial motivation and research (Phutry Lellyzzia, 2018) explains that entrepreneurial knowledge has a significant positive effect on entrepreneurial motivation. Therefore, the higher the entrepreneurial knowledge received by students, it can directly increase entrepreneurship motivation

5. Hypothesis 5 - Effect of Entrepreneurship Characteristics and Knowledge on Motivation Entrepreneurship

The research findings show that hypothesis 5 is proven which states that entrepreneurial characteristics and knowledge variables have a positive and significant effect on vocational student entrepreneurship motivation. It can be concluded that the characteristics of entrepreneurship together with entrepreneurial knowledge affect student entrepreneurship motivation.

6. Hypothesis 6 - The Effect of Entrepreneurial Motivation on Entrepreneurial Interest

The findings in this study explain that entrepreneurship motivation has a significant positive effect on student entrepreneurial interest. This means that the higher the motivation of students, the more significant the interest in entrepreneurship will have. An entrepreneur must have a strong motivation so that he has a high entrepreneurial desire, with the motivation of an entrepreneur will have a stronger desire to achieve his goals, as stated by Howe (in Djaali, 2013: 104).

Motivation has an important role to encourage students to do entrepreneurship in the future. This is in line with the results of research conducted by (Agus Kurniawan, Muhammad Khafid, Amin Pujiati, 2016) explaining that motivation influences interest in entrepreneurship directly.

7. Hypothesis 7 - Effect of Characteristics, Knowledge and Entrepreneurial Motivation on Interest

Entrepreneurship

The findings of this study indicate hypothesis 7 which states that the variable characteristics, knowledge and motivation of entrepreneurship have a positive and significant influence on student entrepreneurial interest. Thus, it can be concluded that the characteristics together with entrepreneurial knowledge and motivation affect student entrepreneurial interest.

8. Hypothesis 8 - The Effect of Motivation Mediates the Characteristics and Knowledge of Self- Organization Towards Entrepreneurial Interest

The research findings show that the motivational variables significantly mediate entrepreneurial characteristics and entrepreneurial knowledge of entrepreneurial interest. This is proven by calculating the VAF value that the entrepreneurial characteristic variable has a partial effect of mediation on the motivational variable on entrepreneurial interest (VAF value $=41.29$ percent, which ranges from $20 \%$ - 80\%) while the entrepreneurial knowledge variable also has a partial effect of mediation on the motivation variable towards entrepreneurial interest $(\mathrm{VAF}$ value $=58.35$ percent, which ranges between $20 \%-80 \%)$. This is consistent 
with conditions in the field where students who have high entrepreneurial motivation tend to have high entrepreneurial interests, compared to other students.

\section{CONCLUSIONS AND RECOMMENDATIONS}

Based on the results of research and discussion in previous chapters, some conclusions and recommendations can be drawn.

\section{Conclusion}

From the previous analysis and discussion, it can be concluded:

1. Variable characteristics of entrepreneurship have a significant positive effect on student entrepreneurial interest.

2. Variable characteristics of entrepreneurship have a significant positive effect on student entrepreneurial interest.

3. Variable characteristics of entrepreneurship have a significant positive effect on student entrepreneurship motivation.

4. The variable entrepreneurship knowledge has a significant positive effect on student entrepreneurship motivation.

5. Variable characteristics and entrepreneurial knowledge have a significant positive effect simultaneously on student entrepreneurship motivation.

6. Entrepreneur motivation variable as a mediating variable in this study has a significant positive effect on student entrepreneurial interest.

7. Variable characteristics, knowledge and entrepreneurial motivation have a significant positive effect simultaneously on student entrepreneurial interest.

8. Entrepreneur motivation variables significantly mediate the entrepreneurial characteristics and knowledge variables of student entrepreneurial interest.

\section{Suggestions}

Based on the results of the analysis of the discussion and some conclusions above, the suggestions that can be given to supplement the results of this study include the following:

\section{For Schools}

It is suggested that schools give more serious attention to the dimensions that have the highest correlation, because it will have a large positive impact on increasing entrepreneurial interest, because it functions as a lavarage or as a lever variable, looking at the value of analysis of correlations between dimensions between characteristics and entrepreneurial knowledge of entrepreneurial interest which shows the highest number is the dimension of applying leadership to the innovation dimension of 0.631 , and the dimension of actualizing attitudes towards the risktaking dimension of 0.698 , so schools need to do several things as follows:

a. There is a need for entrepreneurship lessons in vocational schools which include learning to manage entrepreneurship, both in terms of finance, marketing, operations and human resources, thereby increasing students' knowledge of entrepreneurship.

b. The addition of entrepreneurial extracurricular is also needed to form the leadership spirit of each student so that with the leadership spirit will foster student motivation in entrepreneurship. 
c. Need a routine program about entrepreneurship at least an annual program that involves all students whose aim is to guide students in conducting small entrepreneurs so as to make students motivated to open their businesses in the future.

2. For Further Research

The expectation of the personal writer is to further explore the variables related to the interests of entrepreneurship. The importance of the effect of entrepreneurial motivation as a mediator on entrepreneurial interests found in this study opens up the possibility of other influences that can directly influence entrepreneurial interest, such as external factors in student relationships.

\section{REFERENCES}

A.M. Sardiman. 2012. Interaksi dan Motivasi Belajar Mengajar. PT Raja Grafindo Persada, Jakarta.

Aflit Nuryulia Praswati. Analisis Faktor-faktor yang mempengaruhi Minat Wirausaha di Kalangan Mahasiswa. Studi Kasus: Fakultas Ekonomi dan Bisnis Universitas Muhammadiyah Surakarta. Seminar Nasional dan Call For Paper (Sancall 2014).

Aftina Nurul Husna, Aning Az Zahra, A. L. Amrul Haq. 2018. Skala Karakter Wirausaha (SKWira): Konstruksi dan Validasi Awal. Jurnal Psikologi. Vol. 17, No. 2 Oktober 2018, 143160.

Agus Kurniawan, Muhammad Khafid, Amin Pujiati (2016). "Pengaruh Lingkungan Keluarga, Motivasi, dan Kepribadian Terhadap Minat Wirausaha Melalui Self Efficacy". Journal of Economic Education 5 (1) (2016)

Aima, Muhammad Havidz and R.D. Pranaputra. (2019). The Effect of Workload and Compensation on Motivation and the Implication on Employee Performance of Directorate General of Postal Devices and Resource and Informatics Ministry. International Journal of Innovative Science and Research Technology.

Aima Havidz. (2015). Entrepreneurship dan Peluang Usaha. Jakarta: Inmedia.

Alba Zurriaga-Carda, 2016. Effects of Risk Attitude, Entrepreneurship Education and SelfEfficacy on Entrepreneurial Intentions: A Structure Equation Model Approach to Entrepreneurship. International Review of Management and Business Research Vol. 5 Issue.4, pp. 1424-1433.

Angga Martha Mahendra, Ery Tri Djatmika \& Agus Hermawan (2017). "The Effect of Entrepreneurship Education on Entrepreneurial Intention Mediated by Motivation and Attitude Among Management Students, State University of Malang, Indonesia”. International Education Studies; Vol. 10, No. 9; 2017.

Badan Pusat Statistika (2019), Keadaan Ketenagakerjaan Indonesia 2019, Badan Ketenagakerjaan Indonesia Februari 2019, No. 41/05/Th. XXII, 06 Mei 2019.

Badan Pusat Statistika (2019), Keadaan Ketenagakerjaan Banten Agustus 2019, Keadaan Ketenagakerjaan, No. 63/11/36/Th.XIII, 5 November 2019.

Basrowi. 2014. Kewirausahaan Untuk Perguruan Tinggi. Bogor: Ghalia Indonesia. 
Buchari Alma. 2013. Kewirausahaan. Alfabeta, Bandung.

Djaali, 2013, Psikologi Pendidikan, PT Bumi Aksara, Jakarta.

Daniela Maresch, Rainer Harms, Norbert Kailer, Birgit Wimmer-Wurm. (2016). "The Impact of Entrepreneurship Education on the Entrepreneurial Intention of Students in Science and Engineering Versus Business Studies University Programs”. Technological Forecasting \& Social Change 104 (2016) 172-179.

Djaali. (2013) Psikologi Pendidikan. Bumi Aksara. Jakarta.

Erbu DOGAN. (2015) "The Effect Of Entrepreneurship Education On Entrepreneurial Intentions Of University Students In Turkey”. Ekonometri ve Istatistik Sayi.23 2015 79-93

Fajarto. Suryono Putro, Aima. Muhammad Havidz, Karsono. Bambang, "The Effect Of Compensation and Job Statisfaction On Increasing Productivity Of Asuransi Jasindo Head Office Employees Mediated by Motivation Variable” International Journal of Innovative Science and Research Technology, Volume 4, Issue 7, July - 2019.

Ghozali, Imam. (2011). Partial Least Squares (SmartPLS 3.0). Universitas Diponegoro. Semarang.

Ghozali, Imam. (2016). Aplikasi Analisis Multivariate Dengan Program: IBM SPSS 23. Edisi Ke-8. Semarang, Badan Penerbit: Universitas Diponogoro

Ika Prima Melyana, Rusdarti, Amin Pujiati. (2015). "Pengaruh Sikap dan Pengetahuan Kewirausahaan, Terhadap Kesiapan Berwirausaha Melalui Self Efficac". Journal Economic Education Vol. 4 No. 1, pp. 8-13.

Lia Lusiana Ritonga, Juanda Sianipar. 2016. Hubungan Pengetahuan Kewirausahaan dan Hasil Belajar Kontruksi Kayu dengan Minat Kewirausahaan Siswa Kelas XI Program Keahlian Teknik Konstruksi Kayu SMK Negeri 1 Lubuk Pakam. Education Building, Vol. 2. No. 1 Juni 2016.

John Wiley and Sons. (2013). Metode Penelitian Untuk Bisnis. Edisi Enam. Buku Satu. Salemba Empat. Jakarta.

John Wiley and Sons. (2013). Metode Penelitian Untuk Bisnis. Edisi Enam. Buku Dua. Salemba Empat. Jakarta.

Meri Rahmania. (2016). "Pengaruh Pengetahuan Kewirausahaan, Praktik Kerja Industri dan Motivasi Berprestasi Terhadap Minat Berwirausaha Siswa Kelas XII Kompetensi Keahlian Pemasaran SMK Negeri Bisnis dan Manajemen Kota Padang”. Journal of Economic and Economic Education Vol.4 No.1 (75-86)

Murad Husni Abdulwahab, MBA, Dr. Rula Ali Al-Damen. 2015. “The Impact of Entrepreneurs' Characteristics on Small Business Success at Medical Instruments Supplies Organizations in Jordan". International Journal of Business and Social Science Vol. 6, No. 8; August 2015.

Nurul Fauziyah. "Pengaruh Pengetahuan Kewirausahaan, Self Efficacy dan Karakter Wirausaha Terhadap Minat Berwirausaha (Studi Kasus Pada Mahasiswa Administrasi Bisnis Fisip Unmul Angkatan 2015 dan 2016).

Robbins dan Judge. (2015). Perilaku Organisasi. Edisi Enam belas. Salemba Empat. Jakarta. 
Riduwan. (2010). Skala Pengukuran Variabel-variabel Penelitian. Bandung. Alfabeta.

Siswoyo Haryono. (2017). Metode SEM Untuk Penelitian Manajemen AMOS LISREL PLS. Luxima. Depok.

Slameto. (2010). Belajar dan Faktor-faktor yang mempengaruhinya, Rineka Cipta. Jakarta

Suryana. (2013). Kewirausahaan Pedoman Praktis: Kiat dan Proses Menuju Sukses. Salemba Empat. Jakarta.

Tri Handayani (2016), "Hubungan EQ, Pengetahuan Kewirausahaan dan Hasrat Marginal Menabung Dengan Motivasi Berwirausaha Mahasiswa Pendidikan Ekonomi. Harmoni Sosial”. Jurnal Pendidikan IPS Vol. 3 No. 1, Maret 2016, pp. 95-104.

Wiyono, Gendro. 2011. Merancang Penelitian Bisnis Dengan Alat Analisis SPSS 17,0 \& Smart PLS 2,0. Yogyakarta: UPP STIM YKPN 